\title{
Influence of active mineral additives on the basic properties of the gypsum cement- pozzolan binder for the manufacture of building products
}

\author{
Rustem Mukhametrakhimov ${ }^{1, *}$, Albert Galautdinov ${ }^{1}$ and Liliya Lukmanova ${ }^{1}$ \\ ${ }^{1}$ Kazan State University of Architecture and Engineering, Zelenaya str., 1, Kazan, 420043, Russia
}

\begin{abstract}
The diversity of active mineral admixtures of different origin, mineral composition, dispersion and activity, including by-products in many industrial processes necessitates investigating their properties and characteristics of interaction with gypsum cement compositions. Completed research allowed to define the hydraulic activity of the investigated mineral admixtures and their effect on the rheological and mechanical properties of the composite binder, as well as to determine their optimal content in the mixture. It was shown that the use of the tested active mineral admixtures in optimal amounts allows to obtain stable gypsum cement-pozzolanic system and improve the performance properties of products based on them, resulting in increase of the tensile strength in bending from 2 to $48 \%$, at a compression - from 4 to $49 \%$ and can significantly extend the range of use them in the manufacture of a broad spectrum of building products.
\end{abstract}

\section{Introduction}

The gypsum cement-pozzolanic binder is currently used in construction as a dry building mixes, source raw material for producing finishing, decorating and acoustical materials, as well as parting walls. The gypsum cement-pozzolanic binder is a product based on thorough mixing of the gypsum binder with portland cement or slag cement and pozzolanic additive.

The widespread gypsum cement-pozzolanic binder is caused by their high performance, such as the relatively high flexural strength and compression, high fire resistance, thermal and acoustic insulation characteristics, as well as fast curing.

Active mineral admixtures are traditionally used for the purpose of full implementation the potential of gypsum cement compositions, to avoid ettringite, to increase the density, frost resistance and corrosion resistance, while keeping the strength characteristics. Active mineral admixtures allow to control the formation of the microstructure and properties of the stone based on the composite binder [1-4].

*Corresponding author: muhametrahimov@mail.ru 
As is widely known, the binder composite deformation when hardening depends on its interaction with active mineral admixtures and, depending on the type of active mineral admixtures may occur opposite effects [5]. Dispersed reinforcement gypsum cement matrix allows a significantly decrease the shrinkage strain and swelling strain through the use of a wide range of fibers [6-8].

Both in Russia and abroad by-products are used as a active mineral admixtures, such as silica fume, granulated slag, ceramsite dust and etc. It is efficient to improve the environmental situation in the regions with developed industry [9-13]. The effective application of multicomponent active mineral admixtures in gypsum cement-pozzolanic system, such as milled furnace slag and bergmeal, zeolite-containing primary rocks and limestone, zeolite-containing primary rocks and silica fume [14], milled ceramsite dust and granulated blast-furnace slag in conjunction with lime and superplasticizing admix [15] has been reported. It is also known that mechanochemical activation allows to adjust the formation of structure and properties of curing composites [16].

The aim of the study is determining optimum content of the studied active mineral admixtures as part of the gypsum cement-pozzolanic binder and their influence on the rheological and mechanical properties of the composite binder.

\section{Experimental section}

The following materials were used in the research process:

a) binder:

- gypsum G6BII of manufacture of Ltd Arakchinski gips, in accordance with GOST 125-79;

- portland cement PTS500-D0-H of manufacture of Belgorod cement factory;

b) active mineral admixtures:

- kaolin (TS 5729-016-48174985-2003, a scientific production enterprise OOO Promyshlenye mineraly Togliatti, Russia); , $\mathrm{S}_{\mathrm{f}}=1357 \mathrm{~m}^{2} / \mathrm{kg}$., kaolinite content $95 \%$ with additives of $\beta$-quartz and $\mathrm{Fe}_{2} \mathrm{O}_{3}$, water extract $\mathrm{pH} 8.3$;

- metakaolin obtained by calcination of kaolin at a temperature of $700{ }^{\circ} \mathrm{C}$ for 1 hour, $\mathrm{S}_{\mathrm{f}}$ $=1357 \mathrm{~m}^{2} / \mathrm{kg}$;

- activated metakaolin (metakaolin-A) obtained by activating with an organic acid metakaolin [17], $\mathrm{S}_{\mathrm{f}}=1357 \mathrm{~m}^{2} / \mathrm{kg}$;

- industrial waste iron and steel industry - ferrosilicon, milled up to $\mathrm{S}_{\mathrm{f}}=391 \mathrm{~m}^{2} / \mathrm{kg}$. Chemical constitution, \%: $\mathrm{Si}-63.7 ; \mathrm{Al}-2.5 ; \mathrm{C}-0.1 ; \mathrm{S}-0.02 ; \mathrm{P}-0.05 ; \mathrm{Mn}-0.4 ; \mathrm{Cr}-$ 0.4 ;

- granulated blast furnace slag, $\mathrm{S}_{\mathrm{f}}=230 \mathrm{~m}^{2} / \mathrm{kg}$, (TS 14-106-864-2009, OAO Severstal). Chemical constitution, \%: $\mathrm{SiO}_{2}-3.08 ; \mathrm{Al}_{2} \mathrm{O}_{3}-9.75 ; \mathrm{FeO}-0.34 ; \mathrm{CaO}-37.15 ; \mathrm{MgO}-$ 11.76; $\mathrm{MnO}-0.28 ; \mathrm{S}-0.81 ; \mathrm{TiO}_{2}-1.83$;

- dead-catalyst of the petrochemical synthesis - aluminum silicate, $\mathrm{S}_{\mathrm{f}}=300 \mathrm{~m}^{2} / \mathrm{kg}$. Chemical constitution, \%: $\mathrm{SiO}_{2}-49.42 ; \mathrm{TiO}_{2}-1.44 ; \mathrm{Al}_{2} \mathrm{O}_{3}-45.85 ; \mathrm{Fe}_{2} \mathrm{O}_{3}-0.89 ; \mathrm{FeO}-$ $0.02 ; \mathrm{MnO}-0.01 ; \mathrm{CaO}-0.13 ; \mathrm{MgO}-0.08 ; \mathrm{Na}_{2} \mathrm{O}-0.09 ; \mathrm{K}_{2} 0-0.07 ; \mathrm{P}_{2} \mathrm{O}_{5}-0.04 ; \mathrm{SO}_{3}-$ $<0.05$; other minor impurities -1.94 ;

- amorphous bergmeal from Djabuzhskoye burgeoning, the Kaluga Region, Russia (content of $\mathrm{SiO}_{2}=52.22 \%, \mathrm{~S}_{\mathrm{f}}=1194 \mathrm{~m}^{2} / \mathrm{kg}$ ). Chemical constitution, \%: $\mathrm{SiO}_{2}-76.80 ; \mathrm{Al}_{2} \mathrm{O}_{3}$ - 4.7; $\mathrm{Fe}_{2} \mathrm{O}_{3}-6.5 ; \mathrm{CaO}$ - 1.6; $\mathrm{MgO}$ - 0.7; п.п.п. - 9.7;

- biosilica Diamix, fineness of grinding $\left(\mathrm{S}_{\mathrm{f}}\right)=20 \mathrm{~m}^{2} / \mathrm{k}$, is a finely divided silica of biogenic origin, obtained as a result of a special bath combines the activation of natural diatomite. Bulk density $270 \mathrm{~kg} / \mathrm{m}^{3}$, water extract $\mathrm{pH}$ 7.4. Chemical constitution, \%: $\mathrm{SiO}_{2}-$ 88.0; $\mathrm{Al}_{2} \mathrm{O}_{3}-6.10 ; \mathrm{Fe}_{2} \mathrm{O}_{3}-2.80 ; \mathrm{K}_{2} \mathrm{O}-1.34 ; \mathrm{MgO}-0.84$; 
- dehydrated diatomite Diasil from Inzenskoye burgeoning, $S_{f}=11.2 \mathrm{~m}^{2} / \mathrm{g}$ of manufacture of Diamix in accordance with TS 5716-013-25310144-2008. Bulk density 350 $\mathrm{kg} / \mathrm{m}^{3}$, water extract $\mathrm{pH}$ 7.42. Chemical constitution, $\%: \mathrm{SiO}_{2}-83.0 \% ; \mathrm{Al}_{2} \mathrm{O}_{3}-5.62 \%$; $\mathrm{Fe}_{2} \mathrm{O}_{3}-2.59 \%$.

c) water:

- piped drinking water in accordance with Russian Standard GOST 23732.

Determination of the hydraulic activity of the studied mineral admixtures was carried out in 2 stages. In the first stage hydraulic activity was determined by the method of mineral supplements, based on an assessment of the ability of active mineral admixtures to absorb calcium hydroxide from its saturated solution, in accordance with Russian Standard GOST 25094-94 (Table 1). At the second stage required amount of active mineral admixtures was determined in gypsum cement-pozzolanic binder which was adjusted by the concentration of the calcium oxide contained in special preparations which are aqueous suspensions of calcined gypsum, portland cement, and active mineral admixtures by the procedure described in [18].

\section{Result section.}

\subsection{Determination of hydraulic activity of the active mineral admixtures and their required containing in the gypsum cement-pozzolanic binder}

Two batches of formulations (3-5 formulations in every batch) containing a different concentration of active mineral admixtures were used to determine required amount of active mineral admixtures in gypsum cement-pozzolanic binder. The first batch was tested after 5 days, the second batch - 7 days after production. $50 \mathrm{ml}$ of an aqueous solution were taken from each flask by filtration through filter paper, which was titrated in the presence of phenolphthalein solution of $0.1 \mathrm{~N}$ hydrochloric acid to determine the concentration of calcium oxide after 5 and 7 days. Then the dependence diagrams in a solution of calcium oxide on the amount of active mineral admixtures were plotted (Figures 1-9).

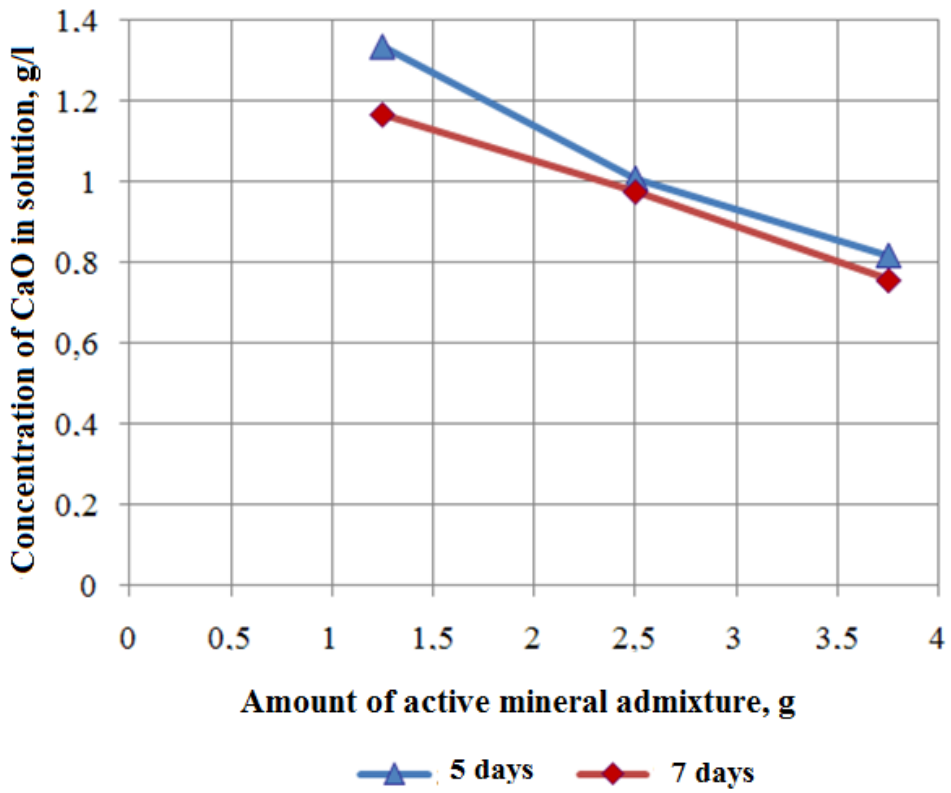

Fig. 1. $\mathrm{CaO}$ absorption kinetics by aluminosilicate additive. 


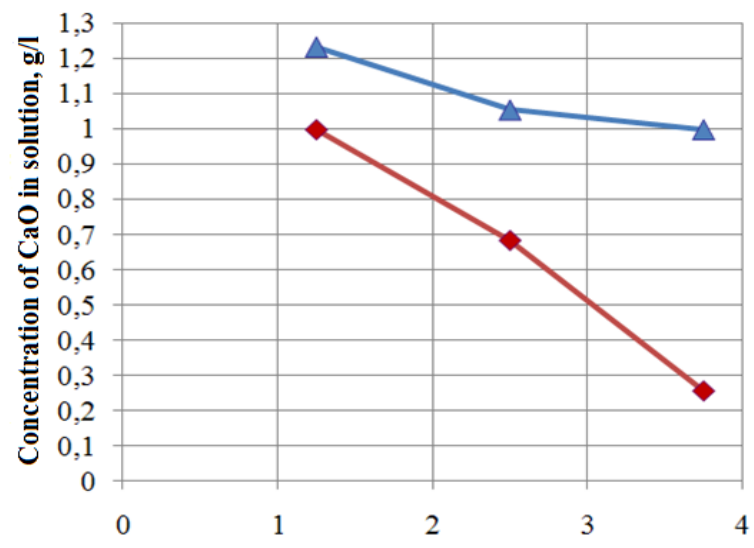

Amount of active mineral admixture, $g$

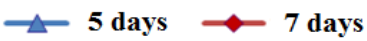

Fig. 2. $\mathrm{CaO}$ absorption kinetics by biosilica.

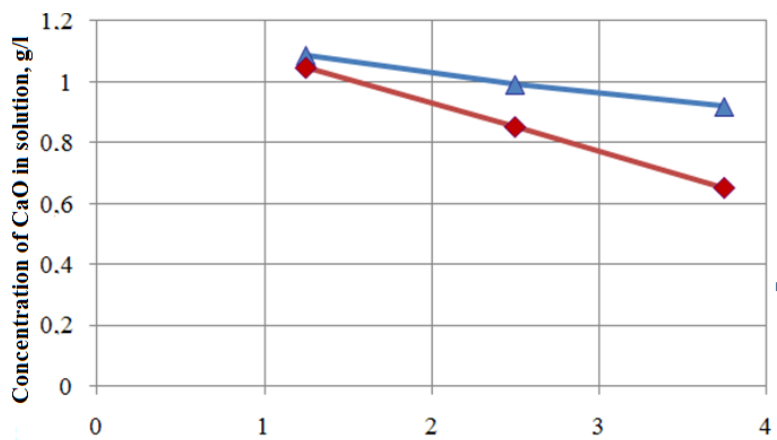

Amount of active mineral admixture, $g$

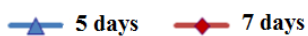

Fig. 3. $\mathrm{CaO}$ absorption kinetics by diatomite additive.

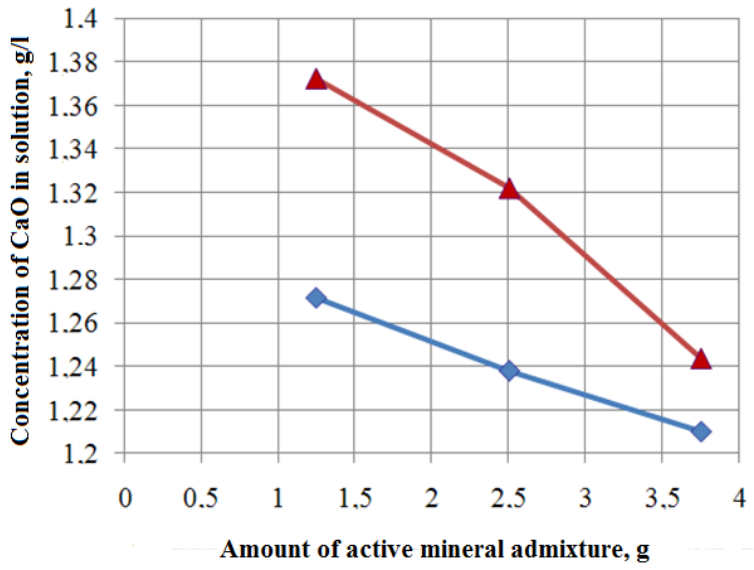

$\neg 5$ days $\longrightarrow 7$ days

Fig. 4. $\mathrm{CaO}$ absorption kinetics by furnace slag additive. 


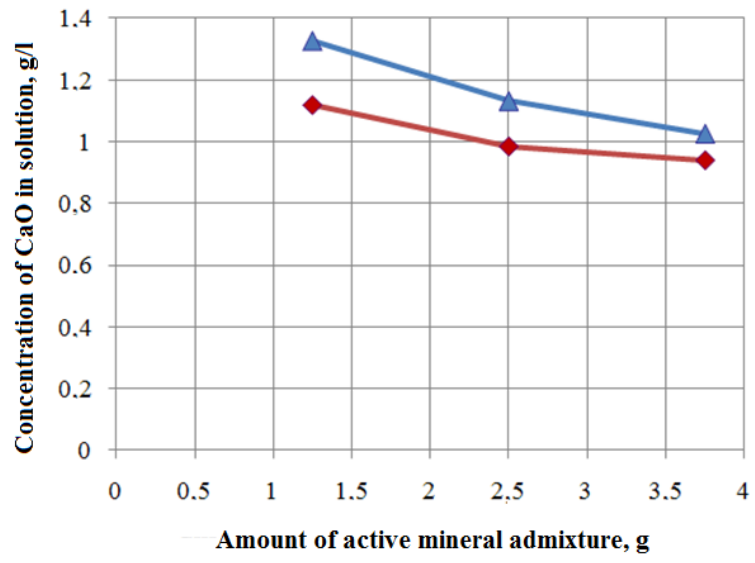

$\multimap 5$ days $\multimap 7$ days

Fig. 5. $\mathrm{CaO}$ absorption kinetics by kaolin additive.

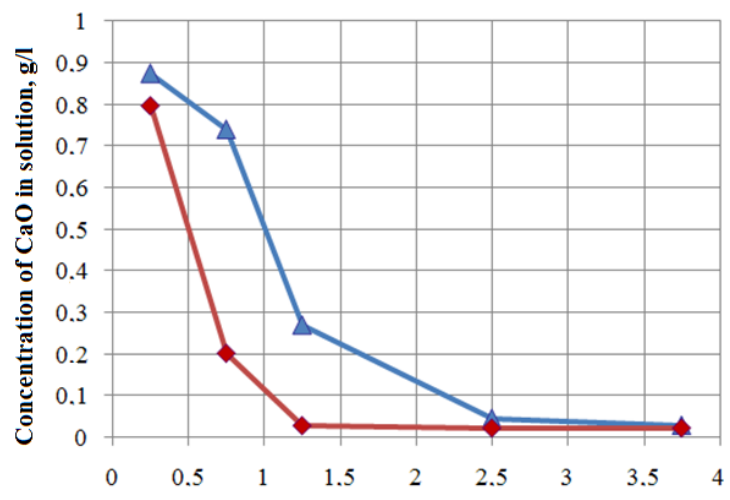

Amount of active mineral admixture, $g$

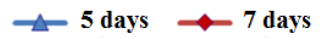

Fig. 6. $\mathrm{CaO}$ absorption kinetics by metakaolin additive.

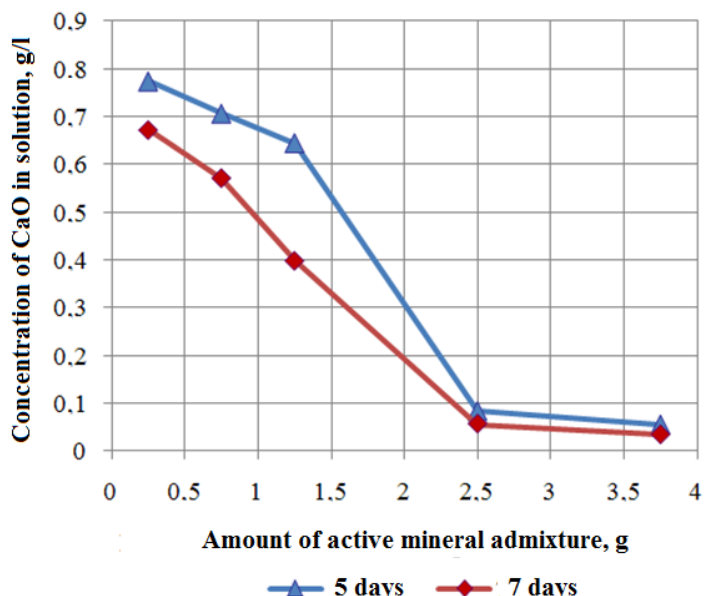

Fig. 7. $\mathrm{CaO}$ absorption kinetics by activated metakaolin additive. 


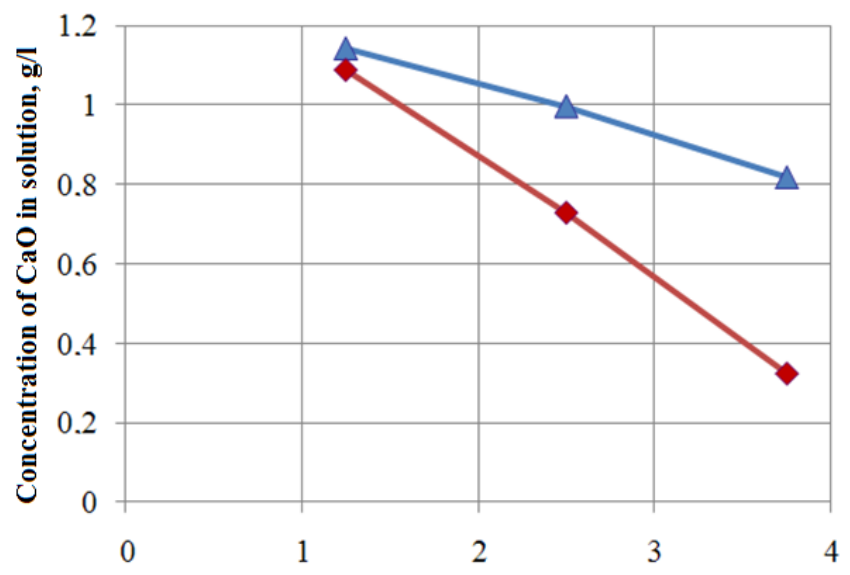

Amount of active mineral admixture, $g$

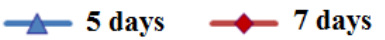

Fig. 8. $\mathrm{CaO}$ absorption kinetics by bergmeal additive.

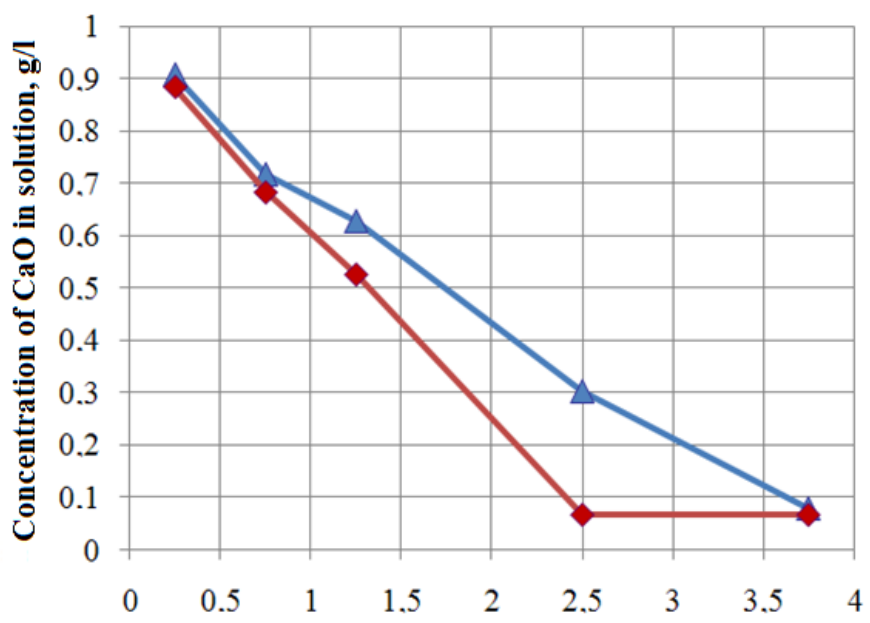

Amount of active mineral admixture, $g$

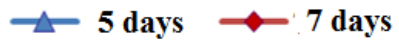

Fig. 9. $\mathrm{CaO}$ absorption kinetics by ferrosilicium additive.

The required amount of active mineral admixtures was chosen in accordance with above diagrams, provided the concentration of calcium oxide was not more than $1.1 \mathrm{~g} / 1 \mathrm{on}$ the fifth day, and was less than $0.85 \mathrm{~g} / 1$ on the seventh day.

Additive consumption was determined by mass. parts per wt. part cement, considering quantities of cement for sample preparation and amount of active mineral admixture produced.

The results of experimental investigations in determining the hydraulic activity of mineral admixtures and required their content in the gypsum cement mixture are presented in Table 1. 
Table 1. Activity of studied mineral additives.

\begin{tabular}{|c|c|c|c|c|}
\hline $\begin{array}{c}\text { Name of active } \\
\text { mineral } \\
\text { admixture }\end{array}$ & $\begin{array}{c}\text { Activity, } \\
\text { mg/g }\end{array}$ & $\begin{array}{c}\mathrm{SiO}_{2} \\
\text { content, } \\
\%\end{array}$ & $\begin{array}{c}\mathrm{Al}_{2} \mathrm{O}_{3} \\
\text { content, \% }\end{array}$ & $\begin{array}{c}\text { Required amount of active } \\
\text { mineral admixture, \% by } \\
\text { weight of the portland cement }\end{array}$ \\
\hline 1 & 2 & 3 & 4 & 5 \\
\hline $\begin{array}{l}\text { Aluminum } \\
\text { silicate }\end{array}$ & 1171.7 & 49.42 & 45.85 & 140 \\
\hline Biosilica & 1489.3 & 88.00 & 6.10 & 100 \\
\hline Diatomite & 1455.9 & 83.00 & 5.62 & 100 \\
\hline Furnace slag & 327.1 & 38.08 & 9.75 & $>150$ \\
\hline Kaolin & 693.0 & 47.53 & 34.42 & $>150$ \\
\hline Bergmeal & 1498.5 & 76.8 & 4.7 & 100 \\
\hline Ferrosilicium & 1450.5 & 63.7 & 2.5 & 20 \\
\hline Metakaolin & 1294 & 47.53 & 34.42 & 20 \\
\hline Metakaolin-A & 1338 & 47.53 & 34.42 & 20 \\
\hline
\end{tabular}

Additives are arranged in the following descending sequence, depending on the activity: bergmeal, biosilica, diatomite, ferrosilicium, metakaolin-A, metakaolin, aluminum silicate, kaolin, furnace slag - as shown in Table 1. However, the minimum active mineral admixtures content required is not directly related to its hydraulic activity by 30 day, determined by the method of GOST 25094-94.

Absorbance values calcium oxide additives furnace slag and the kaolin in the ranges recommended by the method [15] does not satisfy the required conditions. Therefore, it was not possible to establish their required content in the gypsum cement-pozzolanic binder. However, the available data are sufficient to determine that it will be more than $150 \%$ of the portland cement mass.

It can be expected that an excessively high content of active mineral admixtures in the composition of gypsum cement-pozzolanic binder will reduce the strength of the gypsum cement-pozzolanic stone due to the effect dilution of the binder. Therefore, the aluminosilicate additive, furnace slag and kaolin were excluded from the further study.

\subsection{The effect of studing active mineral admixtures on the rheological and mechanical properties of gypsum cement-pozzolanic stone}

Experimental researches have been conducted to determine the effect of optimal content studying active mineral admixtures on the rheological and mechanical properties of the gypsum cement-pozzolanic stone.

The Table 2 presented the results of research on normal consistency changes and setting time of gypsum cement-pozzolanic binder depending on the number of the admixtures of different mineral composition. Degree of filling composite binder by mineral admixture was varied from $4 \%$ to $20 \%$ by mass based on necessary concentration of active mineral 
admixture. The experiment was carried out according to GOST 23789-79 methodology. Results are shown on Table 2.

Table 2. The effect of studied active mineral admixtures on normal consistency and setting time of gypsum cement-pozzolanic binder.

\begin{tabular}{|c|c|c|c|c|c|}
\hline \multirow[b]{2}{*}{ № } & \multirow{2}{*}{$\begin{array}{l}\text { Kind of active } \\
\text { mineral admixture }\end{array}$} & \multirow{2}{*}{$\begin{array}{c}\text { Proportion of } \\
\text { active mineral } \\
\text { admixtures in the } \\
\text { binder, } \%\end{array}$} & \multirow{2}{*}{$\begin{array}{c}\text { Normal } \\
\text { consistency, } \\
\%\end{array}$} & \multicolumn{2}{|c|}{ Setting time, min } \\
\hline & & & & beginning & end \\
\hline 1 & - & - & 0.54 & 5 & 8 \\
\hline 2 & Biosilica & 20 & 0.42 & 31 & 35 \\
\hline 3 & Diatomite & 20 & 0.65 & 24 & 28.5 \\
\hline 4 & Metakaolin & 4 & 0.53 & 7.5 & 10 \\
\hline 5 & Metakaolin-A & 4 & 0.53 & 8 & 10 \\
\hline 6 & Bergmeal & 16 & 0.53 & 20 & 25 \\
\hline 7 & Ferrosilicon & 8 & 0.51 & 6.5 & 8 \\
\hline
\end{tabular}

As indicated in Table 2 different active mineral admixtures have a different impact on setting time of binder. The beginning of setting time with biosilica admixture occurs by 26 minute, but the end occurs later than 27 minutes on which composition with no admixtures. The other admixtures slow down beginning and end setting time in a less degree. The beginning of setting time is achieved by 1.5-19 minutes, but the end - by 1-20.5 minutes later than composition with no admixtures.

Comparing available literary and obtained experimental data indicating the number of active mineral admixtures influences inadequately the setting time of gypsum cement systems. It is evidence that active effect of the active mineral admixtures influences on process of hydration and structurization of these systems.

Active mineral admixtures have a significant impact on the tensile strength in bending and a compression of gypsum cement-pozzolanic stone. For example, by using biosilica the tensile strength in bending and a compression increase by $37 \%$ and $44 \%$ respectively; activated metakaolin - by $28 \%$ and $38 \%$; ferrosilicon - by $2 \%$ and $4 \%$. Adding bergmeal and diatomite to gypsum cement-pozzolanic binder does not increase tensile strength, so in our considered judgement, it linked to effect dilution of composite binder. The highest tensile strength is observed as the metakaolin was used: tensile strength in bending increase by $49 \%$, at a compression by $-48 \%$.

\section{Conclusions}

1. It was determined that studied active mineral admixtures have different activity rate by 5,7 and 30 days. The highest activity rate by absorption $\mathrm{Ca}(\mathrm{OH})_{2}$ by 5 and 7 days was observed as the metakaolin, metakaolin-A, ferrosilicon admixtures were used. This explained their relatively small content required in gypsum cement-pozzolanic binder $(20 \%$ of cement weight or $4-8 \%$ of the total binder mass). The right choice of active mineral admixtures will not allows to prevent formation of ettringite at all stages of curing, so it is important that admixtures continued binding $\mathrm{CaO}$ after 30 days of curing. The highest hydraulic activity by 30 day in addition to the above three additives has also bergmeal, biosilica, diatomite and aluminum silicate, which in our considered judgement, can be used effectively in combination with admixtures which have high activity in the early period of curing.

2. Studying of rheological properties of gypsum cement-pozzolanic stone established that all researched active mineral admixtures in minimum necessary value except for moler reduce normal consistency by $1-12 \%$. The beginning and end of setting time of gypsum 
cement-pozzolanic binder with metakaolin, metakaolin-A and ferrosilicon varies slightly. Biosilica, diatomite and bergmeal had mixtures increasingly slow kinetics entry structurization as demonstrated the lengthening of period of the beginning and the end of the setting time by 15-26 and 17-27 minutes, it is obvious that linked to their high content in the admixture.

3. The most effective active mineral admixtures for gypsum cement-pozzolanic systems on the basis of increasing tensile strength from among studied ones are metakaolin increasing tensile strength in bending by $49 \%$, at a compression - by $48 \%$, as well as biosilica $(37 \%$ and $44 \%)$, metakaolin-A ( $28 \%$ and $48 \%)$.

The results show that the active mineral admixtures influence actively on formation of structure and properties of gypsum cement-pozzolanic stone, therefore, it is of interest for further research.

\section{References}

1. V.S. Izotov, R.Kh. Mukhametrakhimov, A.R. Galautdinov, Stroitel'nye Materialy 725, 20 (2015)

2. G. Mármol, H. Savastano Jr., J. Monzó, M. Borrachero, L. Soriano, J. Payá, Construction and Building Materials 124, 208-218 (2016)

3. M.D. Butakova, S.P. Gorbunov, Procedia Engineering 150, 1461-1467 (2016)

4. A. Vimmrová, M. Keppert, O. Michalko, R. Černý, Cement and Concrete Composites 52, 91-96 (2014)

5. D.G. Sagdatullin, N.N. Morozova, V.G. Hozin, O.M. Il'icheva, Vestnik YUUrGU 15, 51-53, (2010)

6. R.R. Ryazapov, R.Kh. Mukhametrakhimov, V.S. Izotov, Izvestiya KGASU 3 (17), 145-149 (2011)

7. R.Kh. Mukhametrakhimov, V.S. Izotov, Stroitelnye materialy 710, 116 (2014)

8. V.S. Izotov, R.Kh. Mukhametrakhimov, L.S. Sabitov, Scientific Herald 9, 78 (2010)

9. A.N. Luk'janova, I.V. Starostina, Tekhnicheskiye nauki 4, 818-822 (2013)

10. E.A. Gamaliel, Cand. Diss., 217 (2009)

11. A.V. Krylova, T.F. Tkachenko, V.T. Percev, Nauchnyy vestnik VGASU 5, 61-63 (2012)

12. N.M. Krasinikova, N.M. Morozov, I.V. Borovskikh, V.G. Khozin, Magazine of Civil Engineering 51, 46 (2014)

13. N.M. Morozov, I.V. Avksentiev, I.V. Borovskikh, V.G. Khozin, Magazine of Civil Engineering 42, 26 (2013)

14. D.G. Sagdatullin, N.N. Morozova, V.G. Hozin, Izvestiya KGASU 2(12), 263-268 (2009)

15. V.S. Izotov, R.Kh. Mukhametrakhimov, A.R. Galautdinov, Stroitel'nye Materialy 740, $70(2016)$

16. O.B. Kukina, M.P. Stepanova, N.D. Potamoshneva, Nauchnyy vestnik VGASU 2(7), 28-33 (2013)

17. Patent RF 2500633, Declared 04.05.12, Published 12.10.13, Bulletin № 34

18. A.V. Ferronskaja, Gipsovyye materialy i izdeliya. Proizvodstvo i primeneniye (DIA, Moscow, 2004) 